\section{Residue Determination Method for the Insecticide Acetamiprid in Crops by Gas Chromatography}

\author{
Masanori TOKIEDA, Kaname IIYOSHI, \\ Katsumi SugIOKA and Takeshi GoMYO \\ Analysis of Chemicals \& Pesticide Residue, Nisso Chemical \\ Analysis Service Co., Ltd., Takada, Odawara 250-02, Japan
}

(Received March 22, 1996 ; Accepted December 20, 1996)

\section{INTRODUCTION}

An analytical method has been developed for the determination of acetamiprid, $(E)-N^{1}$-[(6-chloro-3-pyridyl)methyl]$N^{2}$-cyano- $N^{1}$-methylacetamidine (ATP) in crops by gas chromatography (GC). ATP in crops was extracted with methanol, purified by liquid-liquid partition and column chromatography and then determined by electron capture detector (ECD)-GC. The limit of detection of ATP for fruits and vegetables was $0.005 \mathrm{ppm}$ and the recovery of fortified samples at $0.1 \mathrm{ppm}$ was about $96 \%$ in average (80-104\%). In case of green tea, the limit of detection of the compound for green tea (powder) and its leachate was $0.05 \mathrm{ppm}$ and the fortified recovery rates ranged from 95 to $98 \%$.

\section{MATERIALS AND METHODS}

\section{Standard Materials}

ATP used in this study was synthesized at Nippon Soda Co., Ltd. and the purity was more than 99\%. The appearance of ATP is white powder and its melting point is 101$103^{\circ} \mathrm{C}$ (Fig. 1).

\section{Reagents}

The organic solvents and inorganic chemicals used in the study were guaranteed reagent purchased from Wako Pure Chemical Industries, Ltd. Florisil (Florisil PR ${ }^{\circledR}$ : non activated) used was produced by Floridon Co. Packed column (Sep Pak ${ }^{\circledR} \mathrm{C}_{18}$ ) was produced by Waters. Celite (No.545) was produced by Johns-Manville Corp.

\section{Apparatus}

Gas chromatograph (Model GC-14B, Shimadzu) equipped<smiles>CNC(C)=NO</smiles>

(E)- $N^{1}-[(6-c h l o r o-3-p y r i d y l)-$ methyl] $-N^{2}$-cyano- $N^{1}$-meth-

Fig. 1 Structures and chemical (abbreviated) name of acetamiprid. with an ECD was used for quantitation. Other apparatuses were a rotary evaporator (Model N-1, Tokyo Rica Kikai), a macerator (Polytron ${ }^{\circledR}$, Kinematica GmbH), a mill (SCM40A, SIBATA), a mechanical shaker (SR-IIw, TAIYO Co.) and balances (Model EB-3200H, Shimadzu, Model H20, Metller). A glass tube for column chromatography was 15 $\mathrm{mm}$ i.d. and $300 \mathrm{~mm}$ length.

\section{Operating Conditions of $G C$}

A 5\% PEG HT/chloromosorb W HP column (60-80 mesh, $3.2 \mathrm{~mm}$ i.d., $1 \mathrm{~m}$ length) was used for the separation. The inlet and detector temperatures were both $320^{\circ} \mathrm{C}$ and column temperature was $260^{\circ} \mathrm{C}$. The carrier gas was nitrogen at a column head pressure of $1.5 \mathrm{~kg} / \mathrm{cm}^{2}$.

\section{Preparation of Calibration Curve}

Calculation of results was based on peak height measurements using calibration curve. The standard curve was obtained by direct injection of $2 \mu \mathrm{l}$ of ATP standard (acetone) for GC in the range of 0.02 to $0.5 \mu \mathrm{g} / \mathrm{ml}$. Calibration curve was prepared by plotting the peak heights $v$ s. the weights of ATP.

\section{Analytical Procedure \\ 6.1 Sample preparation and fortification}

Seven kinds of crops ( 9 matrices) used for fortified recovery tests were obtained from Agricultural Experiment Stations in Japan. Each matrix was cut into pieces with a kitchen knife and homogenized with a mixer. In case of the radish, two portions, the root and leaf, were used separately.

Regarding green tea (powder), leaves dried were ground with a mill.

As for fortification, the experiments were carried out at a range of 0.1 to $2 \mathrm{ppm}$ (refer to Table 2).

\subsection{Extraction \\ 6.2.1 Fruits and vegetables}

The subsamples (except green tea) ( $20 \mathrm{~g}$ ) were homogenized with $100 \mathrm{ml}$ of methanol using the macerator for $3 \mathrm{~min}$ and then shaken for $30 \mathrm{~min}$ by mechanical shaker. The homogenate was filtered through a Celite layer $(1-2 \mathrm{~cm}$ thickness) under reduced pressure. The filter cake and the vessel was washed twice with each $25 \mathrm{ml}$ of methanol and the washings were also filtered through the same Celite layer. These filtrates were combined and transferred to a $500 \mathrm{ml}$ separatory funnel.

\subsubsection{Green tea (Powder)}

The subsample $(4 \mathrm{~g})$ was soaked with $16 \mathrm{ml}$ distilled water for $2 \mathrm{hr}$. Then $100 \mathrm{ml}$ methanol was added to the mixture and it was shaken for $30 \mathrm{~min}$. The subsequent extraction manner is similar to that of fruits and vegetables.

\subsubsection{Green tea (Leachate)}

The subsample $(4 \mathrm{~g})$ was soaked in $240 \mathrm{ml}$ of boiling water 
for $5 \mathrm{~min}$. The mixture was filtered through a filter paper and cooled to ambient temperature. The half volume of the filtrate was subjected to further analysis (corresponds to $2 \mathrm{~g}$ of green tea dried). Five grams of sodium chloride and $120 \mathrm{ml}$ methanol were added to the filtrate and then the aqueous methanol was washed twice with each $100 \mathrm{ml}$ hexane for 10 min. The hexane was discarded. The aqueous methanol was transferred to a $500 \mathrm{ml}$ separatory funnel.

Continue to 6.3 (line 5).

\subsection{Liquid-liquid partition}

Five percents of sodium chloride solution $(150 \mathrm{ml})$ was added to the filtrate. The aqueous methanol solution was shaken twice with each $100 \mathrm{ml}$ hexane for $10 \mathrm{~min}$. The hexane layer was discarded. The aqueous methanol was transferred to an another $500 \mathrm{ml}$ separatory funnel. The aqueous methanol was shaken twice with each $100 \mathrm{ml} \mathrm{di-}$ chloromethane (DCM) for $10 \mathrm{~min}$. In case of summer orange and dry matrices, the DCM layer was washed with 100 $\mathrm{ml}$ of $0.05 \mathrm{~N}$ alkaline solution for $5 \mathrm{~min}$. The alkaline solution was discarded. The DCM solution was passed through a filter paper with anhydrous sodium sulfate and collected in a $300 \mathrm{ml}$ round bottomed flask. One gram of Florisil PR was added to the DCM layer and the DCM solution was. concentrated to dryness in a water bath at $c a .40^{\circ} \mathrm{C}$ under reduced pressure.

\subsection{Column chromatography}

The residue with $1 \mathrm{~g}$ Florisil PR was transferred onto the top of the column packed with Florisil PR $(9 \mathrm{~g})$ with the aid of hexane. The vessel was rinsed twice with each $10 \mathrm{ml}$ of a mixed solvent of acetone and hexane $(20+80, \mathrm{v} / \mathrm{v})$, and the washings was charged to the column. The eluate was discarded. The same mixed solvent described above $(130 \mathrm{ml})$ was passed through the Florisil PR column and the eluate was discarded. Then ATP was eluted with a mixed solvent of acetone and hexane $(50+50, \mathrm{v} / \mathrm{v}, 120 \mathrm{ml})$. The eluate was collected and concentrated to about $10 \mathrm{ml}$ in a water bath at ca. $40^{\circ} \mathrm{C}$ under reduced pressure. The concentrate except summer orange and dry matrices was transferred to a $100 \mathrm{ml}$ of pear shaped flask and dried up under the same manner described above. With regard to summer orange and dry matrices, the eluate collected from Florisil PR column was concentrated dryness in a water bath at $c a .40^{\circ} \mathrm{C}$ under reduced pressure. The residue was dissolved in $5 \mathrm{ml}$ of distilled water and charged on the top of Sep $\mathrm{Pak}^{\circledR} \mathrm{C}_{18}$ pretreated with $20 \mathrm{ml}$ of methanol and then with $20 \mathrm{ml}$ distilled water. The vessel was rinsed three more times with each $5 \mathrm{ml}$ distilled water. Each rinsing was charged on the $\mathrm{C}_{18}$ cartridge and eluted. These water eluates were discarded. The vessel was washed with $30 \mathrm{ml}$ of $15 \%$ acetonitrile and the washings was charged on the top of the $\mathrm{C}_{18}$ cartridge. ATP was eluted with the $30 \mathrm{ml}$ of the $15 \%$ acetonitrile solution and the eluate was collected and then concentrated to dryness in a water bath at $40-50^{\circ} \mathrm{C}$ under reduced pressure.

\subsection{GC determination}

The residue was dissolved in a certain volume of acetone.
Two microliters of the solution was injected into the GC. The residue amount of ATP was calculated by the calibration curve prepared previously. Detector lineality, from 0.04 to $1.0 \mathrm{ng}$, was checked daily for ATP.

\section{RESULTS AND DISCUSSION}

\section{Extraction Solvent}

Methanol, a mixed solvent of methanol and $0.1 \mathrm{M} \mathrm{HCl}$ $(75+25, v / v)$, acetonitrile and acetone were checked as extraction solvents for ATP.

The residue amount obtained from methanol was a little higher than that from the other solvents so that methanol was used as the extraction solvent in this study ${ }^{1)}$ (Table 1).

\section{Clean $U p$}

\subsection{Liquid-liquid partition}

The liquid-liquid partitions were investigated between $50 \%$ aqueous methanol and hexane or DCM. Since ATP was not transferred to hexane but transferred to DCM quantitatively, DCM was adopted as extraction solvent of ATP from $50 \%$ aqueous methanol. Whereas hexane was used in order to remove interferences in $50 \%$ aqueous methanol from crops. ATP in DCM was not transferred to diluted alkaline solution $(0.05 \mathrm{~N})$ so that the DCM layer was washed by the alkaline solution as a clean up procedure for summer orange and dry matrices.

\subsection{Column chromatography}

Florisil PR was checked in combination with two kinds of mixed solvents of methanol and DCM (2.5-5.0+97.5-95, $\mathrm{v} / \mathrm{v})$, acetone and hexane $(20-50+80-50, \mathrm{v} / \mathrm{v})$. ATP was eluted under both conditions, but the mixed solvent of acetone and hexane was more effective to remove interferences from crops.

For residue analyses of ATP in summer orange and dry matrices, interferences could not be removed sufficiently by liquid-liquid partitions and Florisil PR column chromatography. Reverse phased column (Sep Pak ${ }^{\circledR} C_{18}$ ) was used as an additional clean up procedure to remove the interferences from summer orange and dry matrices.

\section{3. $G C$ Conditions}

GC condition was investigated by ECD in combination with several kinds of packing materials to get a sharp peak, minimum detectable amount of ATP and separation of ATP

Table 1 Investigation for extraction solvent of ATP from crops (unit : ppm).

\begin{tabular}{lcccc}
\hline & \multicolumn{4}{c}{ Solvent } \\
\cline { 2 - 5 } Crop & MeOH & $\begin{array}{c}0.1 \mathrm{M} \mathrm{HCl}-\mathrm{MeOH} \\
(25+75, \mathrm{v} / \mathrm{v})\end{array}$ & Acetonitrile & Acetone \\
\hline Eggplant & 0.46 & 0.41 & 0.37 & 0.34 \\
Pear & 0.43 & 0.40 & 0.41 & 0.37 \\
Green pepper & 0.78 & 0.71 & 0.80 & 0.72 \\
\hline
\end{tabular}

Figures are average of duplicates. 
Table 2 Fortified recoveries of ATP in 12 matrices by Parent Method.

\begin{tabular}{lccc}
\hline Crop & $\begin{array}{c}\text { Sample } \\
\text { weight } \\
(\mathrm{g})\end{array}$ & $\begin{array}{c}\text { Amount } \\
\text { added } \\
(\mu \mathrm{g})\end{array}$ & $\begin{array}{c}\text { Recovery } \\
(\%)^{\mathrm{a})}\end{array}$ \\
\hline Cabbage & 20 & 2 & 102 \\
Potato & 20 & 2 & 90 \\
Radish (Leaf) & 20 & 2 & 100 \\
Radish (Root) & 20 & 2 & 95 \\
Grape & 20 & 2 & 99 \\
Summer orange & 20 & 2 & 80 \\
$\quad$ (Whole body) & & & \\
Apple & 20 & 2 & 98 \\
Strawberry & 20 & 2 & 104 \\
Green pepper & 20 & 2 & 98 \\
Eggplant & 20 & 2 & 98 \\
Green tea (Powder) & 4 & 2 & 95 \\
Green tea (Leachate) & 2 & 1 & 98 \\
\hline
\end{tabular}

a) Figures are the average of duplicates.

from interferences. As a result, 5\% PEG-HT/Chromosorb W HP was the best packing material. Other than these packed column conditions, a few kinds of capillary columns (widebore type) were checked with ECD-GC. DB-17 (0.53 $\mathrm{mm}$ i.d., $30 \mathrm{~m}$ length, $1.0 \mu \mathrm{m}$ film thickness, produced by $\mathrm{J} \&$ W Scientific) and BPX-35 (0.25 mm i.d., $25 \mathrm{~m}$ length, $0.25 \mu \mathrm{m}$ film thickness, produced by SGE) gave a good result from the view points described above.

Calibration curves were prepared by a linear and a quadratic equations. The coefficient of correlation of the quadratic equation was higher than that of the linear equation.

\section{Limit of Detection and Fortified Recovery \\ 4.1 Limit of detection}

The minimum detectable amount of ATP was $0.04 \mathrm{ng}$. The limit of detection was $0.005 \mathrm{ppm}$ (fruits and vegetables) when $20 \mathrm{~g}$ of sample was used and injected $2 \mu \mathrm{l}$ into GC from the final solution $(5 \mathrm{ml})$.

\subsection{Fortified recovery}

The recovery of ATP fortified at $0.1 \mathrm{ppm}$ to $10 \mathrm{kinds}$ of representative crops ( 12 matrices) was $96 \%$ in average (Table 2).

Fortified recovery tests at 0.005 and $0.05 \mathrm{ppm}$ (green tea) gave clear peak of ATP for all matrices (Figs. 2 and 3).

\section{Others}

\subsection{HPLC determination}

The maximal absorption of ATP in distilled water was at $246 \mathrm{~nm}$ and the molecular extinction coefficient was $c a .2 \times$ $10^{4}$. It was possible to adopt a HPLC with UV detector for determination of ATP. Normal phased column, Zorbax BP $\mathrm{NH}_{2}$ in combination with methanol/hexane/DCM $(0.4+$ $10+90, v / v)$ was available for the residue analyses of ATP in many kinds of crops. For reversed phased column, Supelco SIL LC-18 in combination with methanol/water $(3+7, v / v)$ was also available. But chromatograms obtained from GC
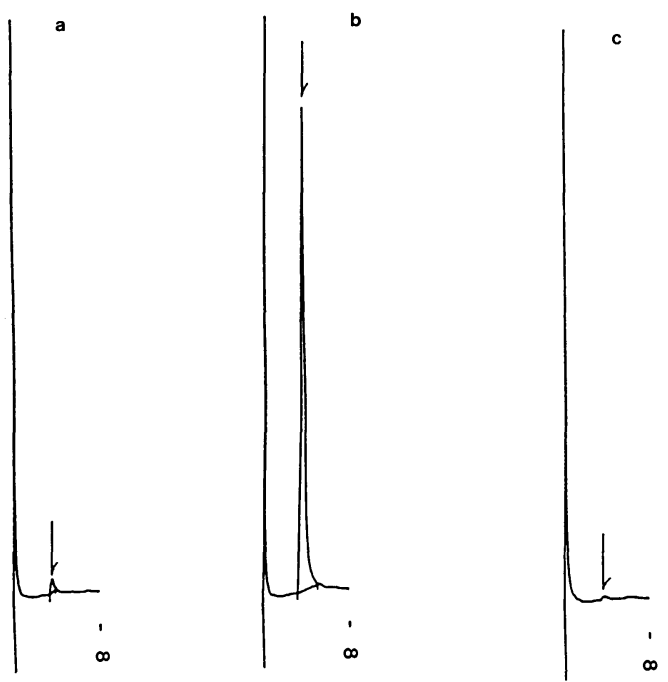

Fig. 2 Examples of GC chromatograms for standard ATP. (a) Minimum detectable amount of ATP $0.04 \mathrm{ng}(2 \mu \mathrm{l})$. (b) ATP $1.0 \mathrm{ng}(2 \mu \mathrm{l})$. (c) Reagent blank $(2 \mu \mathrm{l} / 5 \mathrm{ml})$.
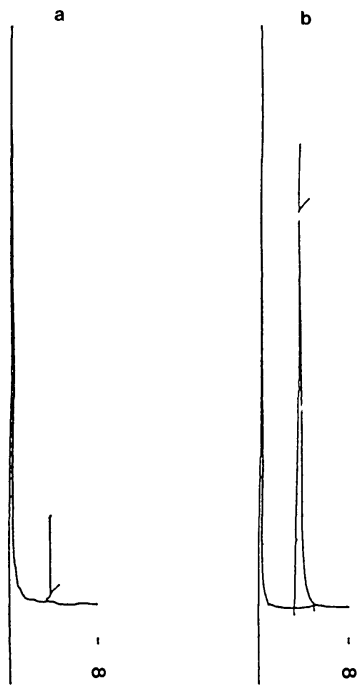

Fig. 3 Examples of GC chromatograms for cabbage.

(a) Cabbage control $(2 \mu \mathrm{l} / 5 \mathrm{ml})$. (b) Fortified recovery of ATP at $0.1 \mathrm{ppm}(2 \mu \mathrm{l} / 5 \mathrm{ml})$.

is better than that from HPLC.

The minimum detectable amount of ATP was $1.0 \mathrm{ng}$. The limit of detection was $0.005 \mathrm{ppm}$ (fruits and vegetables) when $20 \mathrm{~g}$ of sample was used and the final solution was adjusted to $2 \mathrm{ml}$ and $20 \mu \mathrm{l}$ of the final solution was injected into a HPLC.

\section{ACKNOWLEDGMENTS}

We wish to thank Mr. M. Ozawa for his assistance.

\section{REFERENCES}

1) M. Tokieda, M. Ozawa, S. Kobayashi \& T. Gomyo : J. Pesticide Sci. 22, 77 (1997) 
要 約

ガスクロマトグラフィーによる作物中の殺蝓アセタ ミプリドの残留分析法

時枝正則，飯吉 要，杉岡克己，五明 健 新規殺虫剂アセタミプリド $(E)-N^{1}$-[6-chloro-3-pyridyl)meth- yl]- $N^{2}$-cyano- $N^{1}$-methylacetamidine $の$ 作物残留分析法を検討 した。その結果，作物中のアセタミプリドをメタノールで抽出 後, 液々分配およびカラムクロマトグラフィーにより精製した 後，ECD-GCにより定量する方法を確立した。検出限界は果 物・野菜類で $0.005 \mathrm{ppm}$, 茶で $0.05 \mathrm{ppm}$ であり添加回収率 $(0.1$ ppm）は 80〜104\%であった. 